University of Nebraska - Lincoln

DigitalCommons@University of Nebraska - Lincoln

Roman L. Hruska U.S. Meat Animal Research

U.S. Department of Agriculture: Agricultural Center

Research Service, Lincoln, Nebraska

1988

\title{
The Effects of Rate of Change in Body Weight on Tissue Development and Meat Quality of Youthful Bulls
}

John D. Crouse

U.S. Meat Animal Research Center

Chris R. Calkins

University of Nebraska-Lincoln, ccalkins1@unl.edu

Steven C. Seideman

Bryan Meats

Follow this and additional works at: https://digitalcommons.unl.edu/hruskareports

Part of the Animal Sciences Commons

Crouse, John D.; Calkins, Chris R.; and Seideman, Steven C., "The Effects of Rate of Change in Body Weight on Tissue Development and Meat Quality of Youthful Bulls" (1988). Roman L. Hruska U.S. Meat Animal Research Center. 104.

https://digitalcommons.unl.edu/hruskareports/104

This Article is brought to you for free and open access by the U.S. Department of Agriculture: Agricultural Research Service, Lincoln, Nebraska at DigitalCommons@University of Nebraska - Lincoln. It has been accepted for inclusion in Roman L. Hruska U.S. Meat Animal Research Center by an authorized administrator of DigitalCommons@University of Nebraska - Lincoln. 


\title{
The Effects of Rate of Change in Body Weight on Tissue Development and Meat Quality of Youthful Bulls
}

\author{
John D. Crouse, Chris R. Calkins, and Steven C. Seideman
}

\section{Introduction}

Growth and development of meat-producing animals involves a complex integrated system of changes in the structure and mass of body tissues. Researchers have observed and documented that meat animal growth and development may be altered through the diet or alteration of the sex condition. Most significant alterations are in rates of deposition of protein, fat, and connective tissue, as well as the palatability of the cooked meat. Changes in wt of cattle beyond 14 mo of age have been largely associated with the fat deposition in the body. Studies have shown that youthful bulls have advantages in performance of growth and leanness and disadvantages in tenderness when compared with steers. Differences in tenderness have been attributed to variations in fatness and in connective tissue. Connective tissue has been reported to increase markedly at about 12 mo of age and to decrease in solubility with age. These agerelated changes in connective tissue also have been reported to be more pronounced in bulls than steers.

It appears that, as steers are fed dietary energy above maintenance, body protein accretion increases. The alteration in protein content is associated with improved product tenderness. Growth rate over a short period may be a more important determinant of tenderness than the length of time that cattle are fed a high-energy diet. Proteolytic enzymes are needed to increase protein turnover, and these enzymes may also influence postmortem changes in meat properties. Animals gaining or losing wt may alter these enzyme profiles. Therefore, a strong possibility exists that protein turnover is increased and a more youthful connective tissue present during wt gain. This experiment was undertaken to determine the effects of change in body wt on body tissue development and meat quality from youthful bulls.

\section{Procedure}

Animals. Forty-eight Angus bulls about 13 mo of age were used. Bulls were fed a corn and corn-silage growing diet $(74 \%$ TDN) for $4 \mathrm{mo}$ and then placed on a finishing diet ( $84 \%$ TDN) composed of corn and corn silage.

After 30 days on the finishing diet, bulls were randomly assigned to one of three groups: 1) ad libitum-fed (gained $2.2 \mathrm{lb} /$ day), 2) restriction-fed to maintain wt (lost $.35 \mathrm{lb} /$ day), or 3 ) restriction-fed to lose wt (lost $1.26 \mathrm{lb} /$ day). Bulls were penned by treatment and fed in four replicated pens.

After 30 days on trial, two bulls per pen ( 24 bulls total) were slaughtered. The remaining bulls were slaughtered after an additional 30 days on trial. Bulls were slaughtered in the MARC abattoir.

Crouse is the research leader, Meats Unit, MARC; Calkins is an associate professor of animal science, University of Nebraska-Lincoln; Seideman is employed by Bryan Meats, West Point, Mississippi (formerly a research food technologist, MARC).

${ }^{2}$ The full report of this work was published in J. Anim. Sci. 63:1824-1829, 1986.

\section{Results}

Liveweight. Treatment effects due to slaughter group and daily rate of change in wt are given in Table 1. Feeding an additional 30 days had no effect on liveweights or hot carcass wt. Lack of variation in wt associated with slaughter group is primarily due to experimental design. For each unit increase in avg daily gain over the trial, liveweight increased 38 units. Variation in daily rate of change in wt was also reflected in hot carcass wt.

Quality traits. Longissimus muscle at the 12th rib became darker in color, softer, coarser textured, and more physiologically mature when bulls were fed an additional 30 days. Increased daily rate of wt change improved lean texture but had insignificant effects on lean color or maturity scores. These data indicate that age of the animal had more of an effect on lean color and physiological maturity than rate of change of wt.

Composition. No effects due to length of time fed were observed for fat thickness or percentage of rib fat (Table 1). Marbling scores and percentage of kidney and pelvic fat (KPF), however, increased during the final 30 -day feeding period. No changes in longissimus muscle area were observed during the final 30-day feeding period; however, percent lean of the rib tended to decrease with additional time fed. Greater effects due to length of time fed were probably not observed due to design of the experiment. The overall effects of length of time fed included losses in wt as well as gains. Increases in fat deposition within the KPF and longissimus muscle depot sites were associated with increases in physiological age as opposed to increases in body wt.

Daily rate of change in wt (regression coefficients, Table 1) affected composition. Increasing the rate of animal wt gains increased fat deposition within all the fat depot sites, except KPF sites, and decreased percentage of lean in the rib. Longissimus muscle area also increased with increases in daily rates of changes in wt. The present study indicates that quantities of body fat can be altered by varying daily wt change through restriction of diet.

Collagen characteristics. Feeding the additional 30 days or daily rate of change in wt had no appreciable effect on collagen characteristics (Table 1). Decreased solubility of collagen has previously been observed in bulls and with increased age of the animal. Collagen turnover has been observed to be accelerated during periods of rapid growth. Variation in the solubility of collagen also has been associated with meat tenderness.

Sensory characteristics. A slight decrease in flavor intensity was observed to be associated with an additional 30 days of feeding (Table 1). However, this was not associated with daily rate of change in wt. No significant variation in tenderness or other observed sensory characteristics was associated with length of time fed or daily rate of change in wt.

It was anticipated that varying daily gain prior to slaughter would affect tenderness. However, tenderness was not significantly affected by treatments in this experiment.

In the present experiment, intact males were studied instead of castrates. Perhaps degree of maturity of the collagen was altered by the intact male condition of the 
animals studied when comparing results with observations reported in the literature of other sex conditions. Total collagen values in the present study are considerably greater than those previously reported. Collagen in the present study also was observed to be con- siderably less soluble than the collagen in steers of previous studies. Future studies on the growth rate of cattle need to consider interactions of sex conditions. Dietary treatments in the present study failed to affect collagen characteristics in bulls.

Table 1-Slaughter group means and regression coefficients

\begin{tabular}{|c|c|c|c|}
\hline \multirow[b]{2}{*}{ Trait } & \multicolumn{2}{|c|}{ Days fed } & \multirow{2}{*}{$\begin{array}{l}\text { Regression } \\
\text { coefficient }^{\mathrm{a}}\end{array}$} \\
\hline & 30 & 60 & \\
\hline Live $\mathrm{wt}, \mathrm{Ib}$ & 870 & 868 & $38^{* *}$ \\
\hline Hot side wt, lb & 260 & 260 & $10^{\star *}$ \\
\hline Lean colorb & 5.34 & $4.60 * *$ & .13 \\
\hline Lean firmness ${ }^{b}$ & 5.30 & $4.54^{\star}$ & .16 \\
\hline Lean textureb & 5.59 & $4.71^{*}$ * & .18 \\
\hline Lean maturityc & A 26 & $A^{33 * *}$ & .09 \\
\hline Skeletal maturityc & $A^{24}$ & $\mathrm{~A} 32^{* *}$ & .45 \\
\hline Overall maturityc & A25 & $\mathrm{A} 33^{\star *}$ & $0^{.70}$ \\
\hline Marblingd & SI15 & SI72 & $16^{\star}$ \\
\hline Fat thickness, in & .17 & .15 & $.03^{* *}$ \\
\hline Adj. fat thickness, in & .15 & .14 & $.02^{\star \star}$ \\
\hline Longissimus muscle area, in 2 & 11.5 & 10.7 & $.28^{* *}$ \\
\hline KPF, \% & .53 & $1.61^{\star \star}$ & .05 \\
\hline Rib fat, $\%$ & 17.9 & 17.2 & $1.45^{* *}$ \\
\hline Rib bone, $\%$ & 21.5 & $23.7^{\star \star}$ & $-.91^{* *}$ \\
\hline Rib lean, \% & 59.7 & 58.5 & $-.54^{\star}$ \\
\hline Total collagen, $\mathrm{mg} / \mathrm{g}$ & 4.51 & 4.56 & .04 \\
\hline Insoluble collagen, $\%$ & 84.2 & 83.8 & .04 \\
\hline Cooking loss, $\%$ & 39.2 & 38.6 & .05 \\
\hline Juicinesse & 5.12 & 5.20 & .00 \\
\hline Ease of fragmentatione & 5.17 & 4.94 & .04 \\
\hline Amount of connective tissue ${ }^{f}$ & 5.12 & 4.87 & .06 \\
\hline Overall tendernesse & 5.18 & 4.96 & .05 \\
\hline Flavor intensitye & 5.25 & $5.12^{*}$ & .02 \\
\hline Off-flavorg & 5.9 & 6.2 & .07 \\
\hline
\end{tabular}

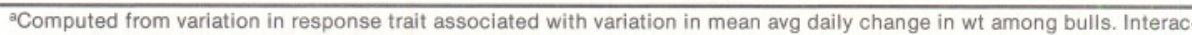
tion regression by slaughter group was not an important source of variation. Unit change/lb.

Scored: 1 = black, very soft, or very coarse to 8 = grayish red, very firm, or very fine.

Scored: 100 to $199=\mathrm{A}, 200$ to $299=\mathrm{B}$.

Scored: 100 to $199=$ traces, 200 to $299=$ slight, 300 to $399=$ small.

Scored: 1 = extremely dry, juicy, difficult, tough, or bland to $8=$ extremely juicy, none, tough, or intense.

Scored: $1=$ abundant to $8=$ none.

Scored: 1 = intense to 4 = none.

$* P<.05$.

$* P<.01$ 